\section{Extraction of Nuclear Proteins with Increased DNA Binding Activity}

BioTechniques 28:938-942 (May 2000)

\begin{abstract}
We have developed a method for the rapid extraction of nuclear proteins from cultured cells. The ammonium sulfate method described here extracts larger quantities of proteins that retain DNA binding activity than the modified Dignam method and another popular method used for the extraction of transcription factors. The ammonium sulfate method is rapid and can be used to process a large number of samples for gel shift analysis.
\end{abstract}

\section{INTRODUCTION}

Electrophoretic mobility shift assays (EMSA) assess the ability of DNA binding proteins to bind to specific nucleotide sequences. The specificity of DNA-protein interactions makes EMSA an invaluable tool for following the expression of transcription factors through various cellular events such as cell growth, growth arrest, apoptosis or differentiation. While working with stably transfected cell lines, our laboratory sought a rapid and easy method to produce nuclear extracts from many samples in a relatively short amount of time for use in gel shift analysis. We sought to minimize not only the labor involved but also the number of cells required to produce a sufficient amount of nuclear extract for gel shift analysis.

The first protocol to isolate soluble nuclear proteins was developed by Dignam et al. and involved the isolation of a crude nuclear fraction from large cell cultures, subsequent high-salt extraction in a buffer containing $420 \mathrm{mM}$ $\mathrm{NaCl}$ and a lengthy dialysis step (2). Andrews et al. modified this protocol for use with much fewer cells and eliminated the need for dialysis (1). These modifications made it possible to use the modified Dignam procedure for the isolation of DNA binding proteins from

Table 1. Ammonium Sulfate Nuclear Extract Protocol

Step 1. Remove cells in wash buffera. Pellet cells and discard supernatant. Perform steps $2-6$ at $4^{\circ} \mathrm{C}$.

Step 2. Resuspend cell pellet in $800 \mu \mathrm{L}$ polyamine bufferb. Add $8 \mu \mathrm{L} 10 \% \mathrm{NP}-40$. Leave on ice for $10 \mathrm{~min}$.

Step 3. Centrifuge at $16000 \times g$ for $2-5$ min to pellet crude nuclei. Discard supernatant.

Step 4. Resuspend nuclei in $600 \mu \mathrm{L}$ polyamine buffer. Underlay with $300 \mu \mathrm{L} 30 \%$ sucrose in polyamine buffer. Centrifuge at $1300 \times \mathrm{g}$ for $10 \mathrm{~min}$.

Step 5. Remove supernatant. Resuspend nuclei in 3-4 volumes $(40-80 \mu \mathrm{L})$ nuclear storage bufferc. Add $0.8 \mathrm{M}$ AS equal in volume to the nuclear slurry. Vortex mix briefly. Leave on ice for 15-20 min.

Step 6. Centrifuge at $16000 \times g$ for $5 \mathrm{~min}$. Spin-dialyze supernatant through a 0.6-mL Bioge ${ }^{\circledR}$ P10 spin column (Bio Rad Laboratories, Hercules, CA, USA) equilibrated in P10 bufferd. Aliquot and flash freeze extracts.

aWash buffer: $10 \mathrm{mM}$ Tris- $\mathrm{HCl}(\mathrm{pH} 8.0), 140 \mathrm{mM} \mathrm{NaCl}$ and $1 \mathrm{mM}$ EDTA.

bPolyamine buffer: $10 \mathrm{mM}$ HEPES ( $\mathrm{pH} 7.9$ ), $10 \mathrm{mM} \mathrm{KCl}, 750 \mu \mathrm{M}$ spermidine, $150 \mu \mathrm{M}$ spermine, $0.1 \mathrm{mM}$ EDTA, $0.1 \mathrm{mM}$ EGTA, $1 \mathrm{mM}$ DTT, $20 \mu \mathrm{g} / \mathrm{mL}$ PMSF, $0.5 \mu \mathrm{g} / \mathrm{mL}$ leupeptin, $1 \mu \mathrm{g} / \mathrm{mL}$ pepstatin, $50 \mu \mathrm{g} / \mathrm{mL}$ chymostatin, $1 \mu \mathrm{g} / \mathrm{mL}$ aprotinin and $50 \mu \mathrm{g} / \mathrm{mL}$ antipain.

cNuclear storage buffer: $50 \%$ glycerol, $20 \mathrm{mM}$ Tris (pH 8.0), $75 \mathrm{mM} \mathrm{NaCl}$ and 0.5 mM EDTA.

dP10 buffer: 20\% glycerol, 20 mM HEPES (pH 7.9), 60 mM KCl and 0.5 mM EDTA.

many different samples simultaneously. The Dignam procedure has since become the method of choice for many researchers studying transcription factors purified from cultured cells. An additional method for the purification of basic leucine zipper or bzip nuclear proteins was developed by Lavery and Schibler and is used for the purification of proteins from tissues such as rat liver (4). This method involves the purification of nuclei and the extraction of nuclear proteins using $1 \mathrm{M}$ urea, $1 \% \mathrm{NP}$ 40 and $300 \mathrm{mM} \mathrm{NaCl}$ (4). Referred to as $\mathrm{NUN}(\mathrm{NaCl}$, urea, NP-40), this method also requires dialysis of the nuclear extract to remove the urea and the detergent, but it still results in a large percentage of denatured and inactive proteins in the extract.

Here, we compare these two methods to a third method we developed in our laboratory for the preparation of nuclear extracts. We have modified and streamlined a method for isolating nuclear proteins from rat liver in which the nuclei are isolated and lysed, followed by extraction of soluble nuclear proteins with $0.4 \mathrm{M}$ ammonium sulfate (AS) (3). The soluble protein fraction is then spin-dialyzed into a buffer compatible with EMSA analysis. This AS method for extracting nuclear proteins takes only about 90 minutes, allows for high sample throughput and generates extracts with high concentrations of intact nuclear proteins that are very active in EMSA analysis. The addition of the spin-dialysis step allows for the rapid removal of solutes that may interfere with EMSA, as well as for flexibility in the final buffer composition. We have found that not only is this method rapid and efficient in extracting DNA binding proteins, but it also extracts larger quantities of active proteins able to bind DNA in gel shift assays.

\section{MATERIALS AND METHODS}

\section{Cell Lines}

Mouse Ltk- aprt- cells were grown in DMEM (Life Technologies, Rockville, MD, USA) supplemented with 


\section{Short Technical Reports}

$10 \%$ calf serum (HyClone, Logan, UT, USA). S6 is a clone of Ltk- cells and can be induced by estradiol to express the transcription factor $\mathrm{C} / \mathrm{EBP} \alpha(\mathrm{K}$. D'Arigo and D.T. Kurtz, unpublished results).

\section{Preparation of Nuclear Extracts from Cultured Cells}

Nuclear extracts were prepared from approximately $2 \times 10^{7}$ cells/sample, though the protocol is successful when used with as few as $1 \times 10^{6}$ cells. Cells were processed as shown in Table 1. For comparison, extracts were also prepared from nuclear pellets obtained as in Table 1, step 4, using either the modified Dignam method (1) or the NUN extraction method (4) and then spin-dialyzed as described in Table 1, step 6 . Typically, from $2 \times 10^{7}$ cells, the AS method yields between 200-300 $\mu \mathrm{g}$ protein, the NUN method yields 250 $350 \mu \mathrm{g}$ and the modified Dignam method yields $100-150 \mu \mathrm{g}$.

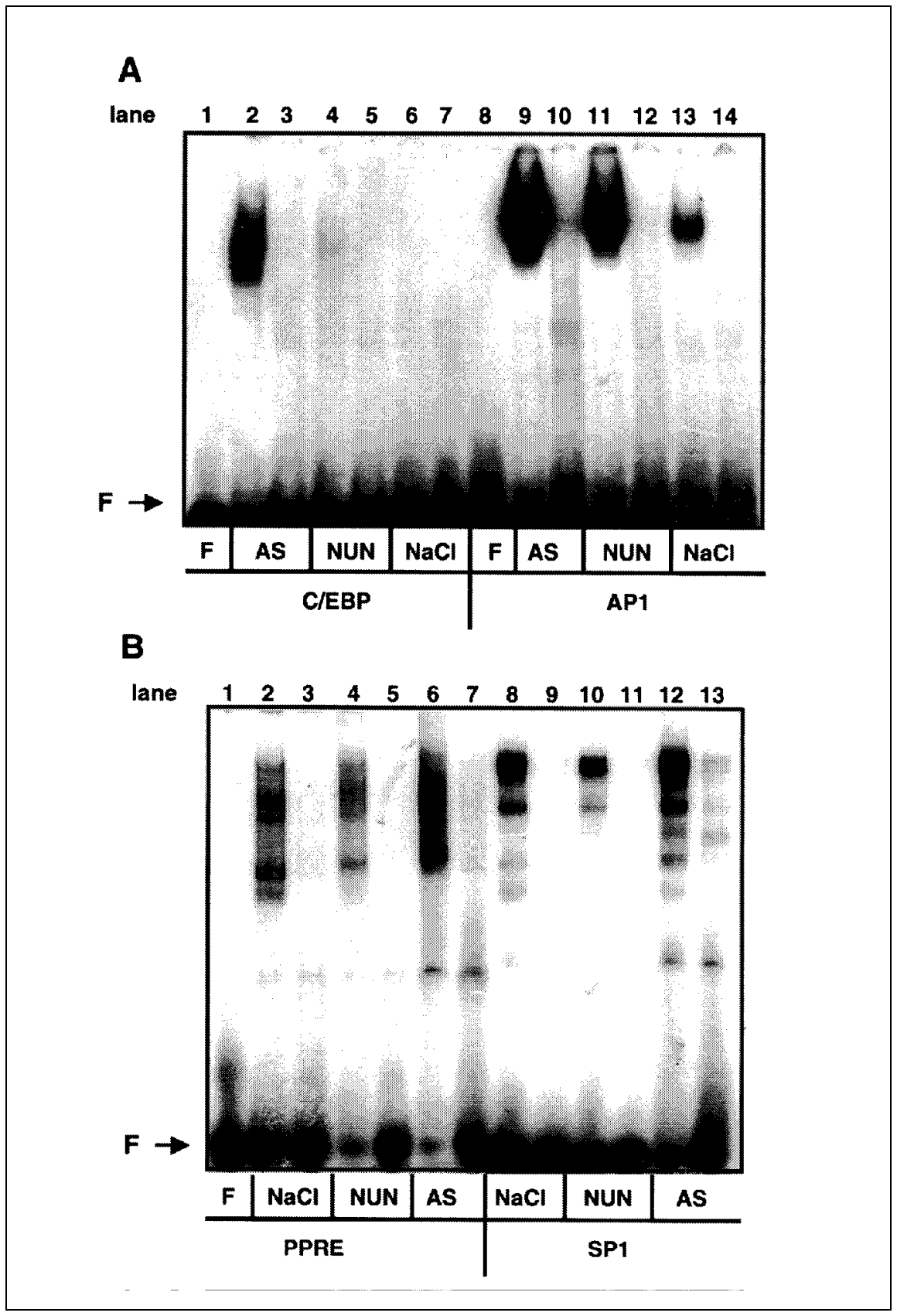

Figure 1. EMSA analysis of nuclear extracts from mouse Ltk- cells prepared by three methods. Nuclear extracts from mouse Ltk-cells were prepared in parallel, and $2.5 \mu \mathrm{g}$ protein were used in EMSA analysis. Free probe $(\mathrm{F})$ is indicated by the arrow at the left. (A) Binding to consensus C/EBP (lanes 1-7) or AP1 (lanes 8-14) sites. Lanes 1 and 8 contain free probe. Ltk- cell extracts were prepared by the AS method (lanes 2, 3,9 and 10), a urea extraction method (NUN) (lanes 4, 5, 11 and 12) or the modified Dignam method $(\mathrm{NaCl})$ (lanes 6, 7, 13 and 14). Nonspecific binding in the presence of unlabeled oligonucleotide is shown in alternate lanes. (B) Binding to consensus PPRE (lanes 1-7) or SP1 (lanes 8-13) site was examined. Lane 1 contains free probe. Ltk- cell extracts were prepared by $\mathrm{NaCl}$ extraction (lanes 2, 3, 8 and 9), NUN extraction (lanes 4, 5, 10 and 11) or AS extraction (lanes 6, 7, 12 and 13). Nonspecific binding in the presence of unlabeled oligonucleotide is shown in alternate lanes. 
phoresis on $5 \%$ polyacrylamide gels at $4^{\circ} \mathrm{C}$ and visualized either by phosphoimaging (Molecular Dynamics, Sunnyvale, CA, USA) or autoradiography.

\section{RESULTS AND DISCUSSION}

\section{Comparison of Nuclear Extract Preparation Methods}

Nuclear extracts were prepared in parallel from mouse Ltk- cells using either the AS method, a urea extraction (NUN) or the modified Dignam highsalt method $(\mathrm{NaCl})$. Equal protein amounts of extracts were subjected to EMSA with a variety of labeled oligonucleotide probes as shown in Figure 1. Increased binding of proteins to all probes was seen to varying degrees using extracts made by the AS method as compared with the $\mathrm{NaCl}$ or NUN methods. Increased binding of
DNA binding proteins to other probes has also been observed from AS extracts (data not shown).

The best example of the difference in the proteins extracted by the three different methods compared here is shown in Figure 1A. Mouse Ltk- cell extracts made by the $\mathrm{NaCl}$ or $\mathrm{NUN}$ method exhibit little or no binding to a consensus $\mathrm{C} / \mathrm{EBP}$ oligonucleotide when $2-5 \mu \mathrm{g}$ protein are subjected to EMSA analysis. However, these cells do produce the transcription factor $\mathrm{C} / \mathrm{EBP} \beta$ as detected by Western analysis of whole cell extracts (data not shown). When Ltk- nuclear extracts are prepared using the AS method, EMSA analysis of $2-5 \mu \mathrm{g}$ protein results in a strong doublet of binding activity that corresponds to the two variant forms of $\mathrm{C} / \mathrm{EBP} \beta$ expressed in these cells, as can be shown by supershift analysis (data not shown). The use of either the $\mathrm{NaCl}$ or NUN method results in extracts con- taining little or no binding of $\mathrm{C} / \mathrm{EBP} \beta$ to its consensus sequence. Similarly, EMSA analysis using consensus AP1, PPRE and SP1 oligonucleotides and equal amounts of protein from the different nuclear extracts shows that a higher percentage of active DNA binding proteins is present in nuclear extracts prepared by the AS method.

\section{Practical Consequence of Improved Protein Yield}

We have created a mouse fibroblast cell line, S6, capable of selective induction of $\mathrm{C} / \mathrm{EBP} \alpha$ using an estradiol-regulated expression system. In the $a b-$ sence of estradiol, cells express only the endogenous $\mathrm{C} / \mathrm{EBP} \beta$ seen in the parental mouse Ltk- cell line. However, after the addition of estradiol, cells also express the related transcription factor $\mathrm{C} / \mathrm{EBP} \alpha$.

Nuclear extracts were prepared in 


\section{Short Technical Reports}

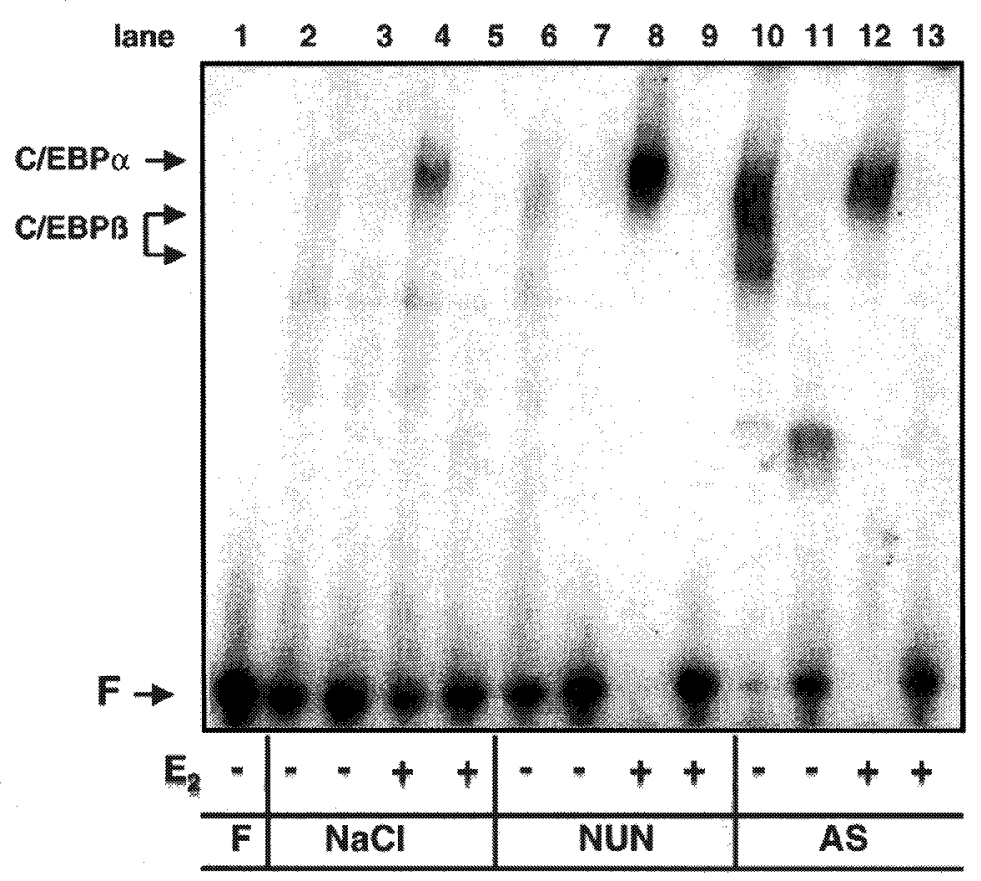

Figure 2. EMSA analysis of nuclear extracts prepared from estradiol-induced SP6 cells by three methods. Nuclear extracts were made in parallel by different methods from S6 cells following treatment with estradiol and induction of the transcription factor $\mathrm{C} / \mathrm{EBP} \alpha$. Protein $(2.5 \mu \mathrm{g})$ was used in EMSA analysis. Lane 1 contains free probe $(\mathrm{F})$, corresponding to a consensus C/EBP binding sequence and is indicated by the arrow at the left. Extracts made from cells treated with estradiol (E2) to induce C/EBP $\alpha$ expression are indicated by (+). Lanes 2-5 contain $\mathrm{NaCl}$ extracts; lanes 6-10 contain NUN extracts; and lanes 10-13 contain AS extracts. Nonspecific binding is assessed in the presence of unlabeled oligonucleotide in alternate lanes. Endogenous $\mathrm{C} / \mathrm{EBP} \beta$ is shown by the double arrow at the left, and induced and slower migrating $\mathrm{C} / \mathrm{EBP} \alpha$ is indicated by the single arrow at the left.

parallel from induced and uninduced S6 cells and equal amounts of protein were analyzed by EMSA for binding to a consensus $\mathrm{C} / \mathrm{EBP}$ binding site recognized by both $\mathrm{C} / \mathrm{EBP} \alpha$ and $\mathrm{C} / \mathrm{EBP} \beta$. As shown in Figure 2, $\mathrm{C} / \mathrm{EBP} \alpha$ is extracted to varying degrees by all three methods, with the NUN and AS sulfate methods yielding the greatest amount of $\mathrm{C} / \mathrm{EBP} \alpha$ binding activity. However, $\mathrm{C} / \mathrm{EBP} \beta$ was only present in extracts produced by the AS method. When lane 10 is compared to lane 12 in Figure 2, a clear difference between the pattern of binding to the consensus $\mathrm{C} / \mathrm{EBP}$ site is evident between the induced and uninduced S6 cell extracts, and it becomes evident that the major $\mathrm{C} / \mathrm{EBP}$ isoform present in induced S6 cells is $\mathrm{C} / \mathrm{EBP} \alpha$. This observation could not have been made had the extracts been prepared by either of the other two methods because the endoge- nous $\mathrm{C} / \mathrm{EBP} \beta$ binding activity is not extracted by $\mathrm{NUN}$ or $\mathrm{NaCl}$ methods.

Using the AS method to prepare nuclear extracts generates larger quantities of protein for EMSA analysis. However, in addition to quantity, extracts produced by this method appear to be enriched in DNA binding proteins that are still active and capable of recognizing cognate binding sequences. The use of a spin-dialysis step prevents the large increase in volume that can occur with standard dialysis methods and significantly shortens the procedure.

\section{REFERENCES}

1.Andrews, N.C. and D.V. Faller. 1991. A rapid micropreparation technique for extraction of DNA binding proteins from limiting numbers of mammalian cells. Nucleic Acids Res. 19:2499.

2.Dignam, J., R.M. Lebovitz and R.R. Roed- er. 1983. Accurate transcription initiation by RNA polymerase II in a soluble extract from isolated mammalian nuclei. Nucleic Acids Res. 11:1475-1489.

3.Gorski, K., M. Carneiro and U. Schibler. 1986. Tissue specific in vitro transcription from the mouse albumin promoter. Cell 47:767-776.

4.Lavery, D.J. and U. Schibler. 1991. Circadian transcription of the cholesterol $7 \alpha$ hydroxylase gene may involve the liver-enriched bZIP protein DBP. Genes Dev. 7:1871-1884.

5.Sambrook, J., E.F. Fritsch and T. Maniatis. 1989. Molecular Cloning: A Laboratory Manual (2nd ed). CSH Laboratory Press, Cold Spring Harbor, NY.

6.Schwartz, D.A. and D.T. Kurtz. 1996. Sequence requirements for secondary glucocorticoid inducibility of rat alpha $2 \mathrm{u}$ globulin genes. Mol. Cell. Endocrinol. 120:153-159.

This work was supported by National Institutes of Health grant no. DK46446, Department of Energy grant no. DE-FCO2$98 \mathrm{CH} 10902$ and an MUSC University Research Committee grant to D.T.K. The expert technical assistance of Susan Brady and Stephanie Cook is gratefully acknowledged. Address correspondence to Dr. David T. Kurtz, Department of Pharmacology, 173 Ashley Ave., P.O. Box 250505, Charleston, SC 29425, USA. Internet: kurtzdt@musc.edu

Received 15 October 1999; accepted 22 February 2000.

\section{Beatrix A. Slomiany, Margaret M. Kelly and David T. Kurtz Medical University of South Carolina Charleston, SC, USA}

